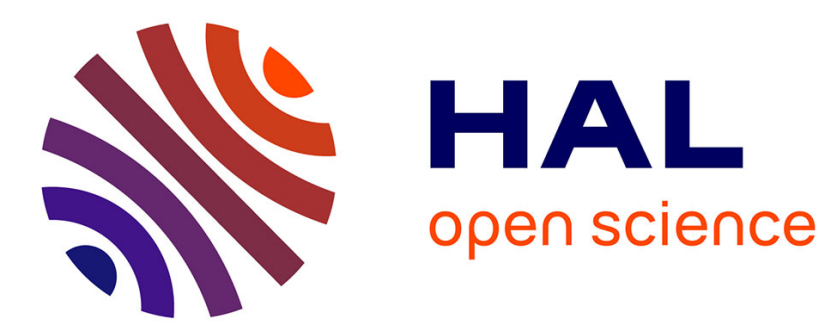

\title{
Development of a Case Study for Eco-Industrial Park Deployment under Uncertainty
}

\author{
E. Kuznetsova, Enrico Zio
}

\section{To cite this version:}

E. Kuznetsova, Enrico Zio. Development of a Case Study for Eco-Industrial Park Deployment under Uncertainty. ESREL 2015, Sep 2015, Zurich, Switzerland. 10.1016/j.egypro.2013.07.028 . hal01232232

\section{HAL Id: hal-01232232 \\ https://hal.science/hal-01232232}

Submitted on 23 Nov 2015

HAL is a multi-disciplinary open access archive for the deposit and dissemination of scientific research documents, whether they are published or not. The documents may come from teaching and research institutions in France or abroad, or from public or private research centers.
L'archive ouverte pluridisciplinaire HAL, est destinée au dépôt et à la diffusion de documents scientifiques de niveau recherche, publiés ou non, émanant des établissements d'enseignement et de recherche français ou étrangers, des laboratoires publics ou privés. 


\title{
Development of a Case Study for Eco-Industrial Park Deployment under Uncertainty
}

\author{
E. Kuznetsova ${ }^{1,2} \&$ E. Zio ${ }^{1,3}$ \\ ${ }^{1}$ Chair on Systems Science and the Energetic Challenge, Foundation EDF, CentraleSupelec, Paris, France \\ ${ }^{2}$ Paris Saclay Energy Efficiency (PS2E), Research and Education Institute, Les Loges-en-Josas, France. \\ ${ }^{3}$ Dipartimento di Energia, Politecnico di Milano, Milano, Italy
}

\section{ABSTRACT}

Eco-Industrial Park (EIP) deployment consists in the creation of physical connections (for example, by a pipeline network) among individual industrial companies (or Individual Actors, IAs) situated in the same geographical area (Gu et al. 2013). These physical connections are used to transmit energy/material generated by some sources IAs to other IAs, which use them to cover their sinks of production and services. EIP deployment can be driven by different potential objectives, i.e., improvement of economic indicators (increase of revenues) and environmental performance. The opportunity of EIP deployment must be evaluated to arrive at optimal choices of deployment. This requires (i) modelling and (ii) optimization, both in presence of uncertainty.

This paper focuses on modelling and aims at developing an industrial case study for Eco-Industrial Park (EIP), under uncertainty. The case study includes the abstract models of IAs quantifying the amounts of energy/material sources, i.e., additional inputs required for raw materials transformation, and sinks, i.e., auxiliary outputs related to the end product fabrication, conditioned by the IAs operation modes (e.g., type of the end products or 'recipe' of the process) and throughput (or production capacity). The objectives for EIP deployment are evaluated via analysis of existent approaches for energy/material processes integration and additional Key Performance Indicators (KPIs) are proposed. The new KPIs framework accounts for economic, environmental and risk attributes, as well as the topological properties of the EIP network.

An EIP case study, based on the real development of Kalundborg (Denmark) (Ehrenfeld and Gertler 2008), and including Oil Refinery and Electricity Power Plant, has been evaluated under present operational conditions and future uncertain scenarios for several decades forward. These scenarios are intended to represent different events related to variation of operational conditions, such as prices for energy and material, and major events related to the future scarcity of material sources, i.e., water, which can provoke supply restrictions, and IA shutdown, which can impact EIP network performance

Based on the evaluation, major recommendations emerge on various issues:

- Scenario forecast and prospection. A variety of scenarios representing major future events must be considered, as they can result in a considerable spread of numerical results of KPIs. Different uncertain factors determine different, i.e., positive and negative, effects on the operational scenario of the different IAs.

- Industrial system modelling. The models of the IAs developed for the case study must be sufficiently detailed to account for changes in various operational scenarios. These IAs models must be reviewed and validated by technical experts to improve and guarantee accuracy.

- EIP optimization. It must be defined whether EIP optimization is done based on a global EIP objective or in a two-steps master-slave optimization, where slave optimization attempts to satisfy IAs objectives under the control of the master optimization ensuring global optimality of EIP. The degree of freedom in slave and master optimization must be identified, depending on IAs implication and level of global authority in EIP development.

\section{REFERENCES}

Ehrenfeld, John, and Nicholas Gertler. 2008. "Industrial Ecology in Practice. The Evolution of Interdependence at Kalunborg." Journal of Industrial Ecology 1 (1): 67-79.

Gu, Chao, Adnan Yassine, Lionel Estel, and Sébastien Leveneur. 2013. "Modeling and Optimization of Material/Energy Flow Exchanges in an Eco-Industrial Park." Energy Procedia 36 (January). Elsevier B.V.: 243-52. doi:10.1016/j.egypro.2013.07.028. 